\title{
Human Factors Influencing the Intention of ICT Appropriation by Healthcare Practitioners: A Survey in Public Centers in Agadir City, South of Morocco
}

\author{
Az-Eddine Bennani ${ }^{1}$, Rachid Oumlil ${ }^{2}$ and Emmanuel Grenier ${ }^{3}$ \\ ${ }^{1}$ Reims Management School, Reims; Université de Technologie de Compiègne, Compiègne, France \\ ${ }^{2}$ Faculté des Sciences Juridiques, Economiques et Sociales de Marrakech (FSJESM), Université \\ Cady Ayyad, Maroc \\ ${ }^{3}$ Reims Management School, Reims, France
}

Correspondence should be addressed to: Az-Eddine Bennani; Az-eddine.bennani@reims-ms.fr

Received date: 24 September 2013; Accepted date: 2 March 2014; Published date: 28 March 2014

Copyright (C) 2014. Az-Eddine Bennani, Rachid Oumlil and Emmanuel Grenier. Distributed under Creative Commons CC-BY 3.0

\begin{abstract}
The resistance to Information technology and communication (ICT) usage is a well-known matter in healthcare area. This study proposes a model that explains the intention of ICT appropriation by physicians and nurses who are involved in the process of care. A survey was conducted in public healthcare centers in Agadir city, located in south of Morocco, to examine the proposed model and to confirm factors that affect positively this intention. Decision makers in healthcare organizations and CIO should consider the importance of these factors to boost the intention of practitioners to use and adopt HIS systems.
\end{abstract}

Keywords: Intention of ICT appropriation, Physicians and nurses, Model, Survey in public healthcare centers, Agadir city in Morocco.

\section{Introduction}

The organization of healthcare is a structure that combines medical and administrative areas. The first is responsible for the care delivery and the second implements procedures and provides tools for the functioning of medical units. This generates various kinds of medical and administrative information. Their Management is increasingly complex (Hodge, 1994). That is why Information Literacy is currently the subject of several strategies of healthcare. The use of Information technology and communication (ICT) in this area is quite recent. Indeed, the first software solution allowing the healthcare organization management appeared late seventies (Eeckman, 2003). The trend is to implement various ways of organizing the delivery of care based on recent developments in the technology (Paré and Sicotte, 2004).

The study conducted in Souss Massa Draa province located in south of Morocco (Bennani et al., 2008), attempted to understand the attitude of the most interested actors in the healthcare area, especially those who are involved directly in the process of the patients care: 
Physicians, nurses, midwives, and administrators. It highlighted the first finding as far as physicians concern in terms of attitude which authors considered as the first step to e-health when it is positive and to the appropriation of ICT. These results provided a view on the positioning of practitioners, especially specialist physicians, in the field of healthcare in this province, in relation with human factors considered with the three other factors (ICT, Task, and Context) in the Zhang and Li model (2004) used for this study. Note that the human factors were tested only by the attitude and the anxiety. For instance, specialist physicians consider that this one is the most important, the ICT comes second, then tasks, and finally the context.

The healthcare public centers, a field of investigation of this complementary research work, face the same challenge. It is an organization whose principal task is the care of patients. It is also a structure that combines several units: Units of care, administrative, medical technology, pharmacy and logistics. It is therefore a complex organization that generates a variety of information (Gremy, 1987). Its performance increasingly depends on a good information management and its control. This communication attempts to answer the question: What are the human factors that influence the intention of ICT appropriation by practitioners in healthcare organizations, especially public centers? It examines other factors such as Self-efficacy, Image, Will, and Personal innovation that might affect the intention of the appropriation of ICT by individuals, particularly, physicians and nurses working for healthcare organization. The study shows the progress of the research work which still going on currently in Morocco. It focuses on the pubic centers of the city of Agadir, in Souss Massa Draa province, located in south of Morocco.

The first section will define the information system and will outline the concept of Hospital Information System (HIS), its objectives, its stakeholders, its main functions, and will highlight some information technologies and communication used in healthcare organizations. The second one, will define the idea of the intention of ICT appropriation by practitioners, the third one, will draw the research model and will state hypothesis. Before concluding the last section will describe the research methodology and findings, and will illustrate the resulting model.

\section{The Information System of the Healthcare Organizations}

The concept of information system is not unambiguous. This is the reason behind each author, emphasizing certain aspects at the expense of others deemed less important, was able to forge its own definition. This multiplicity of definitions reflects the richness of this concept. Davis (1989) incorporates the human factor in this definition, and defines the information system as "a system "user-machine" integrated, which produces information to assist human beings in the management and decision-making."

\section{The Hospital Information System}

The Hospital Information System covers all sectors of a hospital (Dinis et al., 2003) and all the information used in a health facility. It provides an integrated management of information and guarantees its coherence. It makes sure that the information is available anywhere and at any time in reasonable delay. It appears as a cornerstone of care, because it can drive the production of this care, it optimizes the resources committed; it reports on the activity and identifies potential improvements. This system can be seen in three ways: (1) Functional approach that is divided into a set of large areas, themselves divided into several functions (medical, logistical, financial, etc.); (2) Structural approach: its organizational division in the unit of care, technical, administrative service; (3) Process approach: it is analyzed as a sequence of events chained with each other, and whose purpose is to produce quality cares.

The HIS is defined as an environment of software and hardware that takes care of all information systems of a hospital. It facilitates the management of medical and administrative information necessary for the production of care, assessing their quality, resource management and control of activities. In other words, it is a system 
that manages, among other information, medical data and medical record. It is a structure for data transmitted by the different actors of the health system. It concerns different actors that could be grouped into two categories: (1) the internal stakeholders: administrators, physicians, patients, nurses, managers of information systems, etc. working in different area of the hospital (administration, logistics, care unit, medical-technical unit, pharmacy, etc.). (2) External stakeholders: government ministries and agencies, associations, insurance and industry.

An Health Information System should achieve three objective (Beuscart, 1993): (1) Optimize the management of the activity of care by improving information management within the medical unit, (2) Contribute to a better coordination of medical acts, administrative and logistical performed in the hospital; (3) Comply with the strategy and priorities defined by the management. It performs four main functions: (1) the medical and administrative management: identification, admission, transfer, output management applications, billing, (2) resource management: financial management, staff management, bed management, appointments, supply management, (3) the management of the patient and the medical diagnostics, interrogation, clinical examination, examination, examination therapy, nursing , treatment, intervention, monitoring and prognosis, (4) information management: all the information circulating between the diverse actors involved in HIS and/or using it. Its features are based on the functions of information system of any other organization (Dinis et al., 2003). They are summarized in the collection, storing, processing and communication of information from the hospital. These are related to: (1) Diagnosis by the practitioner; (2) Examinations carried out directly on the patient (the time of its passage through the technical, the reasons for its passage, the practice acts and their results; (3) administrative information (patient's marital status...) and medical (medical history, allergies ...).
After this HIS overview, it is necessary to note that it is widely accepted that a successful appropriation of this kind of system by people offer great potential for healthcare organizations to improve their performance (Scott, 2007) and earning the trust of their patients (Ammenwerth et al., 2003, Lu et al., 2005). This requires the involvement of people responsible for the promulgation of care. Hence, the need to study the issue of ICT appropriation by staff, especially, physicians and nurses who work for the healthcare public centers, becomes more and more important. The positive contribution of such system to the quality of care depends then mainly on its appropriation by these practitioners throughout the enactment of such care. The following section develops the issue of ICT appropriation.

\section{Appropriation of ICT and HIS}

The appropriation of ICT, seen as the way it is used, is a complex phenomenon and it is considered as an important competitive advantage (Orlikowski, 2003). It was defined by DeSanctis and Poole (1994) as the process by which people consider technologies in their practices and it is also seen, as the ultimate goal of the usage process (Proulx, 2001).

To explain and predict individual factors of ICT appropriation by healthcare practitioners, Hu et.al (1999), Chau and Hu (2002) evoked the importance of attitude in determining the adoption of telemedicine by physicians. Croteau and Vieru (2002) noted the negative influence of perceived wiliness on the intention of physician working in a large urban healthcare institution.

Banderker and Belle (2006) attempted to identify clearly the factors that influence the adoption of mobile technologies by physicians working in the public sector health care. They noted the importance of self-efficacy and skills to adopt this technology. In addition, Pervan and Schaper (2007) confirmed the significant influence of self-efficacy and attitude of Australia for the therapists to use ICT.

In 2007, Wu et al. developed a conceptual framework to evaluate the intention of healthcare professionals regarding mobile 
healthcare systems adoption. They showed that the self-efficacy influenced the intention to use those systems. In a recent research on the acceptance of a HIS by the Greek hospital staff, Aggelidis and Chatzoglou (2009) found that attitude and self-efficacy influenced significantly their behavioral intention to use ICT.

\section{Research Hypothetical Model and Hypothesis}

Human factors were elucidated by individual factors such as Attitude, Selfefficacy, Anxiety, Image, Commitment, Personal innovation, and Intention (Table 1 in Appendices). The hypothetical research model (Figure 1) gathers these factors that may influence the appropriation of ICT by the actors who intervene in the process of care. It includes the independent variables that enlighten the intention of this appropriation. Furthermore, the intention of the appropriation of ICT is the dependent variable in this model. It is handled as an actual appropriation of these technologies and is understood in terms of frequency of use. In fact, the authors believe that users who adopt the technology accepted it and used it effectively.

Except for the Anxiety that is measured as a binary variable (anxious or not anxious), each of the all other variables was measured using the degree of agreement. For instance, the Attitude as a variable is measured by the means of three items (Bennani et al., 2008): (1) The ICT use for the management and the patient care is a good idea (2) The ICT use for the management and the patient care is beneficial (3) The use of ICT for management and patient care is satisfying. The global hypothesis retained by the authors is:

$\mathrm{H}_{\mathrm{G}}$ : These variables influences positively or negatively the intention of the appropriation of ICT by the actors involved in healthcare. It is broke up into the following hypothesis:

$\mathrm{H}_{\text {Auto-Ef: }}$ Self-efficacy positively influences the intention of the appropriation of ICT by stakeholders involved in the process of healthcare.

$\mathrm{H}_{\text {Anxi }}$ : Anxiety influences negatively the intention of the appropriation of ICT by the participants in the care process.

$\mathrm{H}_{\text {Ima: }}$ The image influences positively the intention for the appropriation of ICT by the participants involved in the process of care.

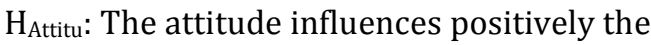
intention of the appropriation of ICT by the participants in the care process.

$\mathrm{H}_{\text {volo: }}$ : The will positively influences the intention of the appropriation of ICT by the participants in the care process.

$\mathrm{H}_{\text {Inn_prs: }}$ the personal Innovation influences positively the intention of the appropriation of ICT by the actors in the process of care. 


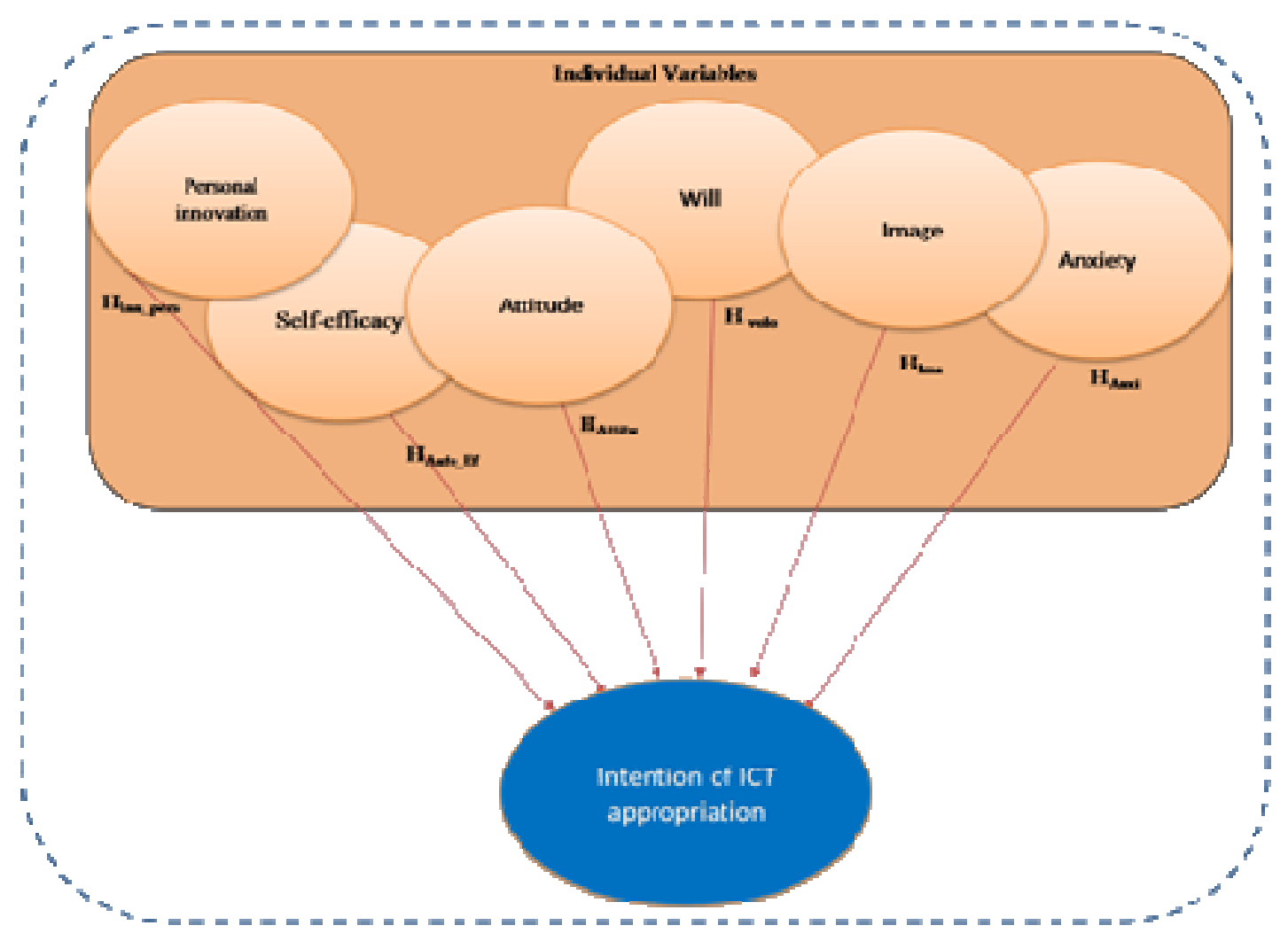

Figure 1 : Hypothetical Research Model

Research Methodology, Data Analysis, Findings, and Resulting Model

The actors who are involved directly in the patients care (physicians and nurses) working for the urban health public centers located in the city of Agadir represent the target population for this study. This corresponds to a total of 145 individuals, divided into 37 physicians and 108 nurses as shown in Table 2.

Table 2: Repartition of target population by healthcare center

\begin{tabular}{|l|l|l|}
\hline $\begin{array}{l}\text { Healthcare } \\
\text { center }\end{array}$ & Physicians & $\begin{array}{l}\text { Nurs } \\
\text { es }\end{array}$ \\
\hline Talborjt & 5 & 7 \\
\hline Essalam & 4 & 9 \\
\hline Bensergaou & 3 & 12 \\
\hline $\begin{array}{l}\text { Erac } \\
\text { bouargane }\end{array}$ & 3 & 10 \\
\hline Tikiouin & 5 & 9 \\
\hline Anza & 3 & 14 \\
\hline $\begin{array}{l}\text { Quartier } \\
\text { industriel }\end{array}$ & 5 & 10 \\
\hline Amsernat & 3 & 10 \\
\hline Elqods & 3 & 14 \\
\hline Ihachach & 3 & 13 \\
\hline
\end{tabular}


The data collection process took place from the beginning of June 2008 and lasted six months, till December, 2008. A set of questionnaires were handed on to major or physician chief of each one of the ten centers, who dealt with their distribution to the various actors of the process of patient care. One week later, a first revival is ensured to get the feed-back from respondents, and to provide explanation whenever it is needed.

The total completed questionnaires were retained for being studied. Data processing was performed using SPSS software package. The response rate achieved was quite high (76.55\%), with 111 replies.

As shown in table 3 , the breakdown of these replies consisted of 30 physicians and 81 nurses. $64.9 \%$ are females and only $35.1 \%$ corresponded to males. Almost the half of the respondents (45.9\%) are older than $40,42.3 \%$ are aged between 25 and 40 , whereas, only $11.7 \%$ who are less than 25.

Table 3: Breakdown and Frequency of the Replies

\begin{tabular}{|l|l|l|l|}
\hline \multirow{2}{*}{ Activity } & Physicians & 30 & $\begin{array}{l}\text { Frequency } \\
\text { (percentage) }\end{array}$ \\
\cline { 2 - 4 } & Nurses & 81 & $27 \%$ \\
\hline \multirow{2}{*}{ Gender } & Male & 39 & $73 \%$ \\
\cline { 2 - 4 } & Female & 72 & $35.1 \%$ \\
\hline & $\begin{array}{l}\text { Less than } \\
25 \text { years }\end{array}$ & 13 & $64.9 \%$ \\
\cline { 2 - 4 } & $\begin{array}{l}\text { Between } \\
25 \text { and } 40 \\
\text { years }\end{array}$ & 47 & $11.7 \%$ \\
\cline { 2 - 4 } & $\begin{array}{l}\text { More than } \\
40 \text { years }\end{array}$ & 51 & $42.3 \%$ \\
\hline
\end{tabular}

Following the preliminary descriptive analysis, a confirmatory analysis is used to check the content validity and reliability of the hypothetical model constructs. First, the reliability of the items used to measure these constructs was checked. The Cronbach's coefficient $(\alpha)$ was used for this issue. Then, the validity of the model was studied using Pearson correlation between these constructs.

Regarding the reliability of the constructs (Table 4 in Appendices), a very good coherence is shown between items of Attitude $(\alpha=0.818)$, Image $(\alpha=0.806)$ and Intention $(\alpha=0.813)$. A good coherence is noted for Self-efficacy ( $\alpha=0.779)$ and Anxiety $(\alpha=0.764)$. However, it reveals a weak reliability for the variables Will $(\alpha=0.009)$ and Personal innovation $(\alpha=0.004)$.

Only Attitude, Self-efficacy, Image and Anxiety constructs are retained, their reliability coefficient being higher than the recommended threshold (0.7). The hypothetical research model is then adjusted to construct a new validated one (Figure2). Only four initial hypotheses are used for the test $\left(\mathrm{H}_{\text {Auto_Ef }}, \mathrm{H}_{\text {Ima }}, \mathrm{H}_{\text {Anxi }}\right.$ and $\left.\mathrm{H}_{\text {Attitu }}\right) . \mathrm{H}_{\text {Inn_pers }}$ and $\mathrm{H}_{\text {Will }}$ hypotheses are removed since their items showed unreliability. 


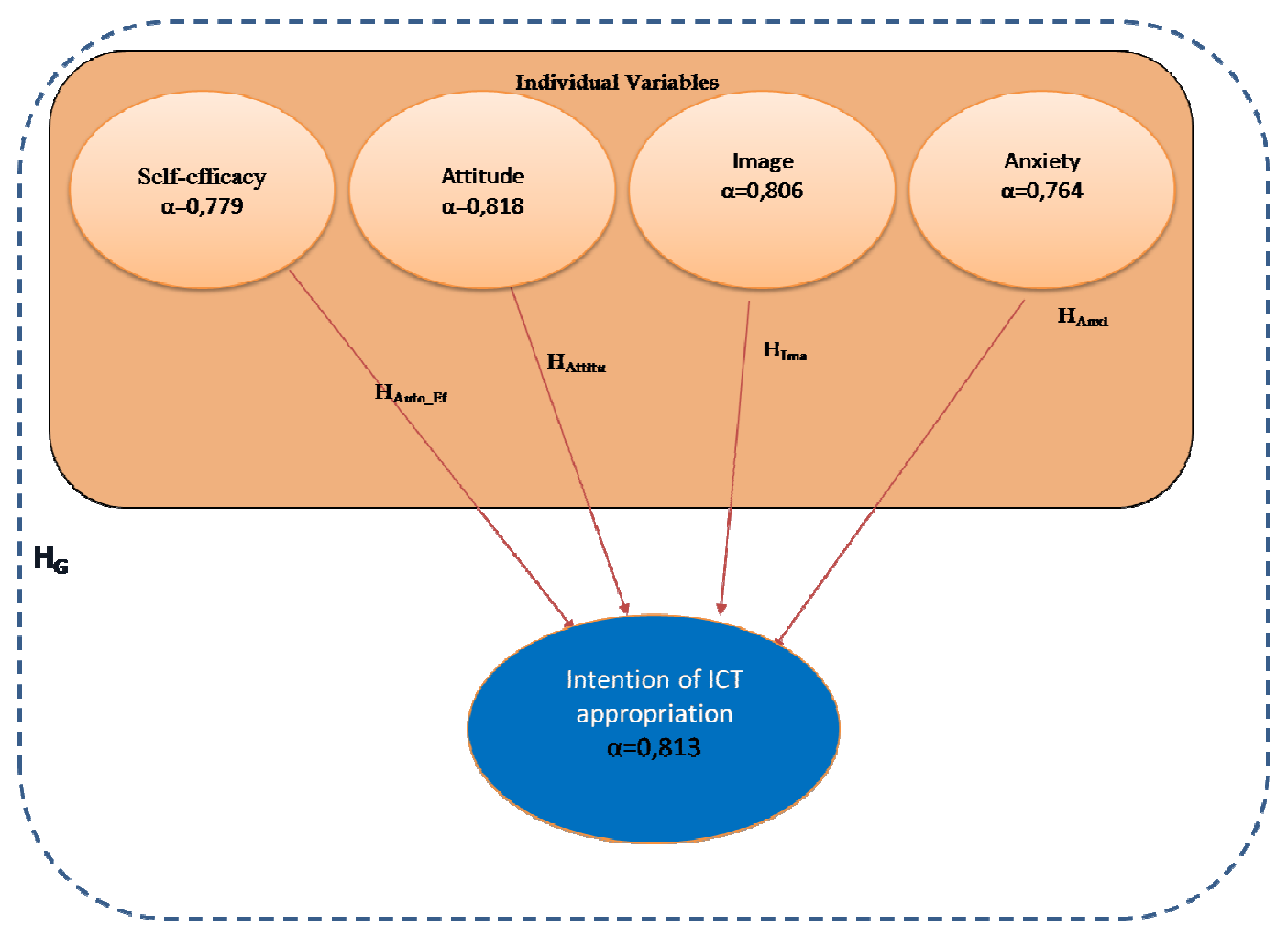

Figure 2: Validated Model

\section{Conclusion}

This research work provides a view on intention of ICT appropriation by healthcare practitioners, especially physicians and nurses working in healthcare public centres, in the city of Agadir located in south of Morocco. Only Attitude and Image showed a significant correlation with the constructs of ICT appropriation (Table 5 in Appendices). These two constructs explained $22 \%$ of the variance of ICT appropriation $\left(\mathrm{R}^{2}\right.$ of the linear regression). They should be considered by decision makers in healthcare organization and by CIO and information system managers who are in charge of HIS systems.

To conclude, this communication confirms the influence of the Attitude factor on the ICT appropriation which strengthen Chau and Hu (2002), Pervan and Schaper (2007), and Aggelidis and Chatzoglou (2009) findings. However, the authors consider this research as pre survey that allows the adjustment of the research model. They recommend reviewing of the constructs that were not retained and their corresponding questions in order to adjust the questionnaire prior administrating it to another category of staff involved in the patient care process.

\section{References}

1. Agarwal, R. and J. Prasad, (1998), "A Conceptual and Operational Definition of Personal Innovativeness in the Domain of Technology," Information Systems Research, 9, 2, June , pp. 204-215.

2. Aggelidis, V.P., Chatzoglou, P.D., (2009), "Using a modified technology acceptance model in hospitals", international journal of medical informatics , 7 8, 115-126

3. Ammenwerth, E., Graber, S., Herrmann,G., Burkle,T., Konig,J., (2003), "Evaluation of health information systems-problems and Challenges", International Journal of Medical Informatics, 71,pp.125-135.

4. Banderker, N. and Van Belle, J.P. (2006), "Mobile technology adoption by doctors in 
public healthcare in South Africa". Proceedings of European Conference in Information Systems, Goteborg 14th, 12-14 , pp.1-13.

5. Bennani, A., Belalia, M., Oumlil, R. (2008), "As Human Factor, the attitude of Healthcare Practitioners is the Primary Step for the e-Health: First Outcome of an Ongoing Study in Morocco, CIBIMA online journal, Volume 3, number 4

6. Beuscart, R., Grave, C., Bricoteau, D., Purro, N. (1993). "Les étapes de définition d'un système d'information hospitalier : la place des utilisateurs". Informatique et Santé, (6), pp 79 -88

7. Chau, P.Y.K. Hu, P.J. (2002), "Investigating healthcare professionals decisions to accept telemedicine technology: an empirical test of competing theories", Information \& Management 39, (4), 297-311.

8. Compeau, D. and Higgins, C. (1995) "Computer Self-Efficacy: Developement of a Measure and Initial Test", MIS Quarterly, June.

9. Compeau, D., C.A. Higgins, and S.L. Huff, (1999), "Social Cognitive Theory and Individual Reactions to Computing Technology: A Longitudinal Study," MIS Quarterly, 23, 2, June, pp.145-158.

10. Croteau AM, Vieru D. (2002), "Telemedicine adoption by different groups of physicians". Proceedings of the 35th Hawaii International Conference on System Sciences,

11. Davis. F.D., (1989), "Perceived usefulness, perceived ease of use and user acceptance of information technology", MIS Quarterly, Vol. 13, $\mathrm{N}^{\circ}$ 3, September, pp. 318-340

12. DeSanctis, G. et Poole, M.S (1994), "Capturing complexity in advanced technology use: Adaptive Structuration theory", Organisation Science, 5 (2), pp 121-146
13. Dinis, A., Silva, J-L., Sigal, R., Lottin, P., (2003). "Système d'information et integration des images à l'institut gustve Roussy", Informatique et santé, (15), pp 147-156

14. Eeckman, I., (2003), "le rôle du département d'information médicale dans la démarche d'accréditation", Informatique et santé, springer-Verlag

15. Grémy, F. (1987) "Informatique Médicale - introduction à la méthodologie en médecine et santé". Paris, Flammarion

16. Hodge MH, (1994). "Traitement des données et stratégie de gestion hospitalière" Informatique et Santé, (11), pp.27-32

17. Hu, P.J. Chau, P.Y.K. Liu O.R. Sheng, K.Y. Tam , (1999) "Examining the technology acceptance model using physician acceptance of telemedicine technology", Journal of Management Information Systems, 16 (2), pp.91-112.

18. Lederer, A. L., Maupin, D. J., Sena, M. P. et Zhuang, Y.(1998) "The role of ease of use, usefulness and attitude in the prediction of World Wide Web usage“; CPR 98 Boston, MA USA;

19. Lu, Y.C., Xiao, Y.,, Sears, A., Jacko, J.A, (2005), "A review and a framework of handheld computer adoption in healthcare", InternationalJournal of Medical Informatics ,74, pp.409-422.

20. Moore, G.C. and I. Benbasat, (1991), "Development of an Instrument to Measure the Perception of Adopting an Information Technology Adoption," Information Systems Research, 2, 3, pp.192-223.

21. Ohinmaa A, Hailey D, Roine R. (1999), "The assessment of telemedicine: General principles and a systematic review", Edmonton: Finnish Office for Health Care Technology Assessment,

22. Paré, G., Sicotte, C., (2004). "Les technologies de l'information et la transformation de l'offre de soins", GreSI, (04) 04 
23. Proulx, S., 2001, "Les formes d'appropriation d'une culture numérique comme enjeu d'une société du savoir", Actes du colloque COREVI "Gouvernance et usages d'internet : vers un nouvel environnement normatif, Montréal,

24. Schaper, L.K Pervan, G.P. (2007), “A model of information and communication technology acceptance and utilization by occupational therapists", International Journal of medical Informatics 76, pp.790800.

25. Scott, R.E.(2007), "e-Records in health-preserving our future", International Journal of Medical Informatics, 76, pp.427-431.
26. Venkatesh,V., and Davis, F.D., (1996), "A Model of the antecedents of perceived ease of use: development and test", Decision Science, vol.27, pp 451-481.

27. Venkatesh, V. (2000), "Determinants of Perceived Ease of Use: Integrating Perceived Behavioral Control, Computer Anxiety and Enjoyment into the Technology Acceptance Model," Information Systems Research, 11, pp.342365

28. Venkatesh,V., and Davis, F.D., (2000), "A Theoretical Extension of the Technology Acceptance Model: Four Longitudinal Field Studies", Management Science, Vol. 46, $\mathrm{N}^{\circ}$ 2, February, pp.186-204 


\section{Appendices}

Table 1: Variables of ICT Appropriation

\begin{tabular}{|l|l|l|l|}
\hline Abbreviation & Variables & Definition & References \\
\hline Auto-Ef & self-efficacy & $\begin{array}{l}\text { Trial of an individual regarding } \\
\text { his ability and his ability to use } \\
\text { technology. }\end{array}$ & $\begin{array}{l}\text { Compeau and Higgins, } \\
\text { 1995.1999; Venkatesh } \\
\text { and Davis, 1996 }\end{array}$ \\
\hline Anxi & anxiety & $\begin{array}{l}\text { Apprehension or fear that an } \\
\text { individual facing the possibility } \\
\text { of using a technology. }\end{array}$ & $\begin{array}{l}\text { Compeau and Higgins } \\
1995 ; \text { Venkatesh, 2000 }\end{array}$ \\
\hline Ima & Self-image & $\begin{array}{l}\text { social approval is sought to } \\
\text { have each individual's } \\
\text { reference group and Davis, }\end{array}$ & $\begin{array}{l}\text { Venkatesh and } \\
2000\end{array}$ \\
\hline Attitu & Attitude & $\begin{array}{l}\text { The attitude favorable or } \\
\text { unfavorable sentiment toward } \\
\text { the use of a technology }\end{array}$ & $\begin{array}{l}\text { Venkatesh and Davis, } \\
1996, \text { Lederer et al. } \\
1998\end{array}$ \\
\hline volo & Innovation & $\begin{array}{l}\text { The degree to which } \\
\text { technology is perceived to be } \\
\text { voluntary }\end{array}$ & $\begin{array}{l}\text { Moore and Benbassat, } \\
1991\end{array}$ \\
\hline
\end{tabular}


Table 4: Reliability of variables

\begin{tabular}{|c|c|c|}
\hline Variable & Cronbach's alpha $(\alpha)$ & Interpretation \\
\hline Attitude & $\alpha=0.818$ & $\begin{array}{l}\text { A very good } \\
\text { coherence } \\
\text { between items of } \\
\text { "Attitude" }\end{array}$ \\
\hline Self-efficacy & $\alpha=0.779$ & $\begin{array}{l}\text { A good } \\
\text { coherence } \\
\text { between items of } \\
\text { "Self-efficacy" }\end{array}$ \\
\hline Image & $\alpha=0.806$ & $\begin{array}{l}\text { A very good } \\
\text { coherence } \\
\text { between items of } \\
\text { "Image" }\end{array}$ \\
\hline Anxiety & $\alpha=0.764$ & $\begin{array}{l}\text { A good } \\
\text { coherence } \\
\text { between items of } \\
\text { "Anxiety" }\end{array}$ \\
\hline Will & $\alpha=0.009$ & $\begin{array}{l}\text { A weak } \\
\text { coherence } \\
\text { between items of } \\
\text { "will" }\end{array}$ \\
\hline Personal innovation & $\alpha=0.004$ & $\begin{array}{l}\text { A weak } \\
\text { coherence } \\
\text { between items of } \\
\text { "Personal } \\
\text { innovation" }\end{array}$ \\
\hline Intention & $\alpha=0.813$ & $\begin{array}{l}\text { A very good } \\
\text { coherence } \\
\text { between items of } \\
\text { "Intention" }\end{array}$ \\
\hline
\end{tabular}


Table 5: Correlation between Retained Variables and the Intention of ICT Appropriation Construct

\begin{tabular}{|l|l|r|r|r|}
\hline & Attitude & $\begin{array}{c}\text { Self- } \\
\text { efficacy }\end{array}$ & Anxiety & Image \\
\hline $\begin{array}{l}\text { Pearson } \\
\text { Correlation }\end{array}$ & 0.373 & 0.126 & -0.139 & 0.340 \\
\hline P-Value & 0.000 & 0.270 & 0.187 & 0.001 \\
\hline
\end{tabular}

